\title{
Transmigrated Canines Associated to Odontomas
}

\author{
Caninos Transmigrados Asociados a Odontomas
}

Carlos Salamanca ${ }^{1,2}$; Nicolás Ernesto Ottone ${ }^{1,3}$; César Arias Rubilar ${ }^{4}$ Ivonne Garay ${ }^{5}$ \& Ramon Fuentes ${ }^{1}$

SALAMANCA, C.; OTTONE, N. E.; ARIAS, R. C.; GARAY, I. \& FUENTES, R. Transmigrated canines associated to odontomas. Int. J. Morphol., 35(2):465-468, 2017.

SUMMARY: We present the case of a 13-year-old patient with bilateral transmigration of mandibular canine associated with multiple composite odontoma. Impacted canines are very uncommon, with a $0.1 \%$ to $3.6 \%$ prevalence of appearance. The presence in the mandible is less frequent. The odontoma development is often associated with the impacted canines. The etiology is unknown but is associated with traumatic, infectious, hereditary or genetic factors. This pathology is asymptomatic and associated with eruption disorders in temporal and permanent dentition.

KEY WORDS: Transmigrated canines; Odontomas; Panoramic radiography; Cone beam ct.

\section{INTRODUCTION}

Impacted canines are considered a rare phenomenon, with a prevalence of $0.1 \%$ to $3.6 \%$ in general population (Aydin et al., 2004), being more frequent in the maxilla than in the mandible, where it only reaches a prevalence between $0.17 \%$ and $0.46 \%$ (Mazinis et al., 2012). It is usually an asymptomatic phenomenon and is located by buccal or lingual of the apexes of the lower incisors. It can cause root resorption and/or inclination of the axial axis of the adjacent teeth (Celikoglu et al., 2010).

The pre-eruptive migration of an impacted or retained canine through the midline is a phenomenon known as transmigration, which occurs more frequently in the mandible than in the maxilla (Aydin \& Yilmaz, 2003), with a reported prevalence in the literature ranging from $0.1 \%$ to $0.34 \%$ (Aktan et al., 2010).

Impacted canines are often associated with the development of odontomas (Mehra \& Singh, 2007; Flores Ruiz et al., 2013; Madiraju et al., 2013; Erdur et al., 2016). Odontomas are the most common odontogenic tumors of the jaw (Vaid et al., 2012). They are mixed tumors consisting of epithelial and mesenchymal cells, composed of dental tissues such as enamel, dentin, pulp and cement (Tyagi \& Singla, 2010).
Odontomas are recognized as developmental disorders and are classified as compounds and complexes (Barnes et al., 2005), the first is twice as common as the second, with a prevalence of $76 \%$ of odontogenic tumors (Buchner et al., 2006). Its etiology is unknown but is associated with traumatic, infectious, hereditary or genetic factors such as hyperactivity of odontoblasts, Gardner's Syndrome or Hermann's Syndrome (Raval et al., 2014).

Clinically they are asymptomatic and associated with eruption disorders in temporal and permanent dentition. Their diagnosis is usually coincidental on routine radiographic examinations or in studies of late dental eruption. Its treatment is surgical for repositioning in the arch the impacted or retained tooth (Erdur et al.; Ashkenazi et al., 2007).

The aim of this study is to present a case of bilateral transmigration of mandibular canine associated with multiple composite odontoma in a 13 -year-old patient.

\section{CASE REPORT}

A 13-year-old female patient attended Clinica Odontologica Docente Asistencial (CODA), Dental School, Universidad de La Frontera, due to the absence of mandibular canines. Extraoral examination showed facial symmetry,

\footnotetext{
${ }^{1}$ Research Center in Dental Sciences (CICO), Dental School, Universidad de La Frontera, Temuco, Chile.

${ }^{2}$ Universidad Adventista de Chile, Chillán, Chile.

${ }^{3}$ Doctoral Program in Morphological Sciences, Medicine School, Universidad de La Frontera, Temuco, Chile.

${ }^{4}$ Departamento de Salud Municipal de Carahue, Carahue, Región de La Araucanía, Chile.

${ }^{5}$ Oral and Maxillofacial Imaging Unit, Dental School, Universidad de La Frontera, Temuco, Chile.
} 
concave profile, Angle class II without alterations (Fig. 1A). At the intraoral examination, multiple restorations were observed, presence of caries and teeth in the state of root rest (Fig. 1B). During the anamnesis, parents informed that the patient was born prematurely and with skin disorders.

As a complementary exam, a panoramic radiography was requested (Fig. 1C). It was observed presence of intraosseous third molars, superficial and deep dental caries, tooth 3,6 with extensive crown destruction, teeth 3,3 and 4,3 included in horizontal position placed in the apical area between the lower right premolars. A radiopaque image of diffuse borders compatible with osteosclerosis is observed. Permanence of tooth 8,3 where is observed an image compatible with composite odontoma.
Cone Beam CT examination is requested (Fig. 1D). Teeth 3,3 and 4,3 are included in ectopic position and mesioversion, tooth 3,3 close to apex of incisors and tooth 8,3 in persistence.

Composed odontoma close to root apex of teeth 8,3, 4,2 and 4,4 and to upper root of tooth 4,3, with a $12,9 \mathrm{~mm} \mathrm{x}$ $8,3 \mathrm{~mm}$ size in the sagittal plane (Fig. 1E) and $9 \mathrm{~mm}$ in the coronal plane (Fig. 1F).

Tooth 4,3 presents its crown under tooth 3,3 crown, bi-radicular and an radiopaque area of rounded form, placed in the middle third of mandibular body, next to foramen mentale compatible with idiopathic osteosclerosis (yellow arrow) (Fig. 1G).

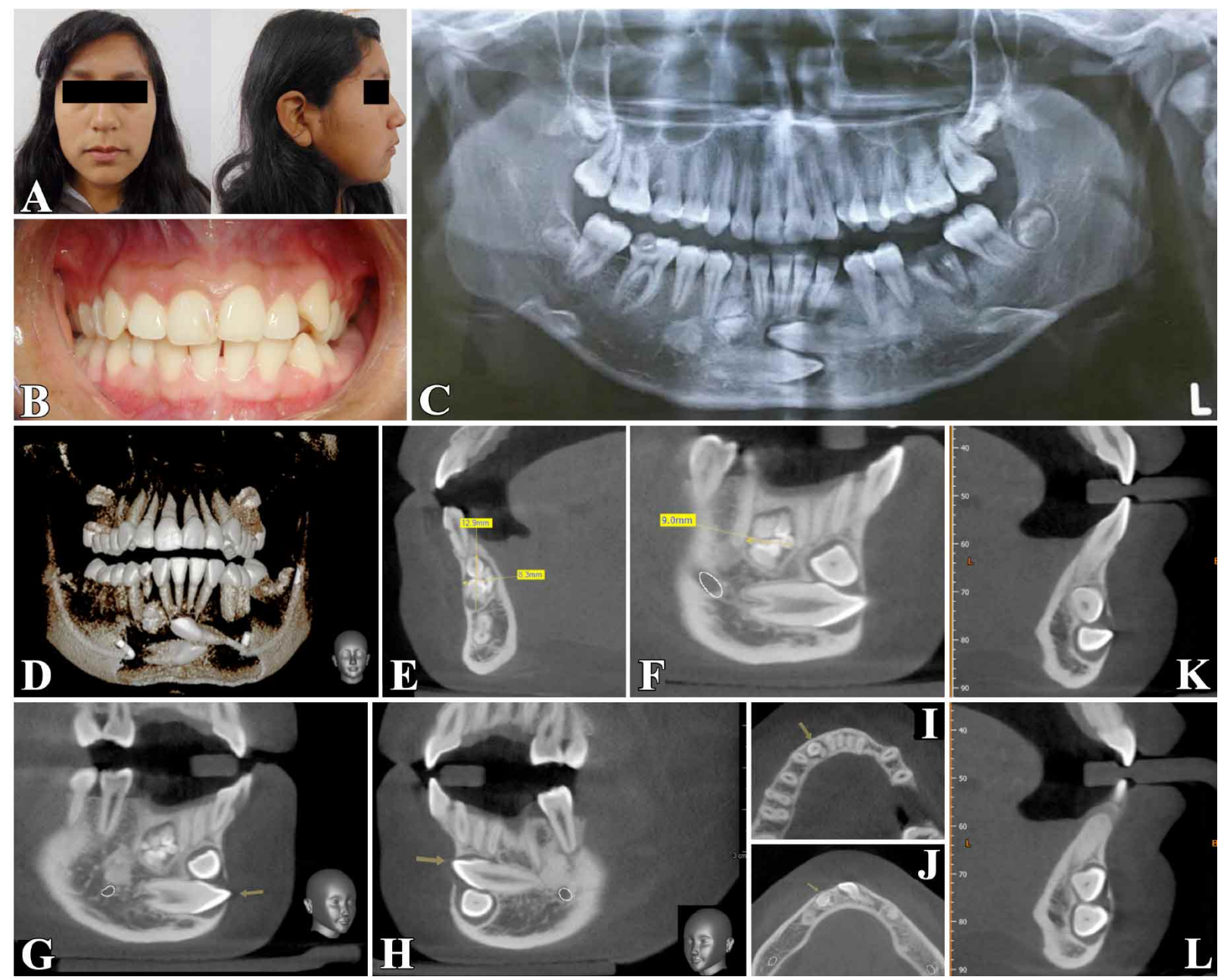

Fig. 1. A. Extraoral examination of the patient. B. Intraoral examination. C. Panoramic radiography, which shows intraosseous third molars, 3,3 and 4,3 teeth placed in horizontal position between the lower right premolars, and permanence of tooth 8,3 compatible with composite odontoma. D. Cone Beam CT examination, with inclusion of teeth 3,3 and 4,3 in ectopic position and mesioversion, persistence of 8,3 tooth. E, F. Composed odontoma close to root apex of teeth 8,3, 4,2 and 4.4 and to upper root of tooth 4,3. G. Tooth 4,3 presents its crown under tooth 3,3 crown, bi-radicular; idiopathic Osteosclerosis next to foramen mentale (yellow arrow). $\mathrm{H}$. Tooth 3,3 presents a pericoronal space of normal thickness, uni-radicular, close to foramen mentale and apex of tooth 4,3, compatible with idiopathic osteosclerosis (yellow arrow). I, J. Axial plane. K, L. Sagittal views at crown levels. 
Tooth 3,3 presents a pericoronal space of normal thickness, uni-radicular and an irregularly shaped radiopaque area placed in middle and upper thirds of mandibular body, between roots of 3,4 and 3,5 teeth, close to foramen mentale and apex of tooth 4,3 , compatible with idiopathic osteosclerosis (yellow arrow) (Fig. 1H).

\section{DISCUSSION}

Migration of canines through the midline is named transmigration. Although the etiology has not been clearly described, one of the factors that may favor transmigration is a large cross-sectional area of the anterior region of the mandible (Aydin et al.). Some authors have described as possible etiological factors such as the presence of supernumerary teeth, tumors of odontogenic origin, cysts, hereditary factors and traumas (Joshi, 2001).

Thoma (1952), Shapira et al. (1982) and Taguchi et al. (2001) attributed canine transmigration to the presence of odontomas, as well as in our case where bilateral mandibular canine transmigration can be attributed to the persistence of temporal canines associated with odontomas located at the apex level. This may had caused deviation in the trajectory of permanent canine eruption and its transmigration. However, it cannot be ensured that the presence of the odontoma is responsible for the transmigration or the pathological condition occurred after the transmigration of canines (Joshi).

Mupparapu (2002) had classified transmigration into five types based on the pattern of migration and the position of the canines in the mandible. The case would present the Type I variant of transmigration, ie, canine retained mesio angularly under the incisors, labial or lingual, across the midline. The studies reported left canine to be more frequently affected by transmigration, while our case presented with a permanent transmigrated right canine.

The treatment modalities suggested in the literature include surgical extraction, transplantation, orthodontic alignment after crown exposure and observation. Most authors prefer surgical extraction as their treatment option, which however, depends on the stage of development and the distance of the migrated canine (Aydin \& Yilmaz; Aydin et al.; Mehra \& Singh; Aktan et al.; Celikoglu et al.; Mazinis et al.; Flores Ruiz et al.; Madiraju et al.; Erdur et al.).

The elimination of odontoma that results in the improvement of the canine position has been suggested in the literature. In the present case, the early diagnosis of the phenomenon would have facilitated the removal of the retained temporal canine and thus odon- improved the normal eruption of the right mandibular permanent canine in its correct position. In fact, when the patient was asymptomatic and unaware of the condition, early diagnosis was not possible. Periodic observation that includes a series of subsequent radiographs was chosen because of the impacted and asymptomatic nature of the canine migrated in the present case, which corroborates with the recommendation of other authors (Aydin \& Yilmaz; Aydin et al.; Mehra \& Singh; Aktan et al.; Celikoglu et al.; Erdur et al.; Buchner et al.; Vaid et al.).

Although they are asymptomatic, complications such as root resorption of adjacent teeth, formation of cysts, infections and pain due to pressure on the lower dental nerve can justify the long-term follow-up of the phenomenon at regular intervals.

SALAMANCA, C.; OTTONE, N. E.; ARIAS, R. C.; GARAY, I. \& FUENTES, R. Caninos transmigrados asociados a odontomas. Int. J. Morphol., 35(2):465-468, 2017.

RESUMEN: Presentamos el caso de un paciente de 13 años de edad con trasmigración bilateral de canino mandibular asociado a múltiples odontomas compuestos. Los caninos impactados son muy poco frecuentes, con una prevalencia de aparición de 0,1 $\%$ a 3,6 \%. La presencia en la mandíbula es menos frecuente. El desarrollo de odontomas se asocia a menudo con los caninos impactados. La etiología es desconocida pero está asociada con factores traumáticos, infecciosos, hereditarios o genéticos. Esta patología es asintomática y está asociada a trastornos de erupción en dentición temporal y permanente.

PALABRAS CLAVE: Caninos transmigrados; Odontomas; Radiografía panorámica; TC Cone beam.

\section{REFERENCES}

Aktan, A. M.; Kara, S.; Akgünlü, F. \& Malkoç, S. The incidence of canine transmigration and tooth impaction in a Turkish subpopulation. Eur. J. Orthod., 32(5):575-81, 2010.

Ashkenazi, M.; Greenberg, B. P.; Chodik, G. \& Rakocz, M. Postoperative prognosis of unerupted teeth after removal of supernumerary teeth or odontomas. Am. J. Orthod. Dentofacial Orthop., 131(5):614-9, 2007.

Aydin, U. \& Yilmaz, H. Transmigration of impacted canines. Dentomaxillofac. Radiol., 32(3):198-200, 2003.

Aydin, U.; Yilmaz, H. H. \& Yildirim, D. Incidence of canine impaction and transmigration in a patient population. Dentomaxillofac. Radiol., 33(3):164-9, 2004.

Barnes, L.; Eveson, J. W.; Reichart, P. \& Sidransky, D. Pathology and Genetics of Head and Neck Tumours. Lyon, World Health Organization Classification of Tumours, IARC Press, 2005.

Buchner, A.; Merrell, P. W. \& Carpenter, W. M. Relative frequency of central odontogenic tumors: a study of 1,088 cases from Northern California 
and comparison to studies from other parts of the world. J. Oral Maxillofac. Surg., 64(9):1343-52, 2006.

Celikoglu, M.; Kamak, H. \& Oktay, H. Investigation of transmigrated and impacted maxillary and mandibular canine teeth in an orthodontic patient population. J. Oral Maxillofac. Surg., 68(5):1001-6, 2010.

Erdur, E. A.; Ileri, Z.; Ugurluoglu, C.; Cakir, M. \& Dolanmaz, D. Eruption of an impacted canine in an adenomatid odontogenic tumor treated with combined orthodontic and surgical therapy. Am. J. Orthod. Dentofacial Orthop., 149(6):923-7, 2016.

Flores Ruiz, R.; Simón Sánchez, E.; Yáñez-Vico, R. M.; Torres Lagares, D. \& Gutiérrez-Pérez, J. L. Odontoma compuesto asociado a canino permanente inferior incluido. Gac. Dent., 244:120-7, 2013.

Joshi, M. R. Transmigrant mandibular canines: a record of 28 cases and a retrospective review of the literature. Angle Orthod., 71(1):12-22, 2001.

Madiraju, G. S.; Rao, K. S. \& Singamaneni, V. A rare case of transmigration of mandibular canine associated with an odontoma. B. M. J. Case Rep., pii:bcr2013009658, 2013

Mazinis, E.; Zafeiriadis, A.; Karathanasis, A. \& Lambrianidis, T. Transmigration of impacted canines: prevalence, management and implications on tooth structure and pulp vitality of adjacent teeth. Clin. Oral Investig., 16(2):625-32, 2012.

Mehra, P. \& Singh, H. Complex composite odontoma associated with impacted tooth: A case report. N. Y. State Dent. J., 73(2):38-40, 2007.

Mupparapu, M. Patterns of intra-osseous transmigration and ectopic eruption of mandibular canines: review of literature and report of nine additional cases. Dentomaxillofac. Radiol., 31(6):355-60, 2002.

Raval, N.; Mehta, D.; Vachhrajani, K. \& Nimavat, A. Erupted odontoma: A case report. J. Clin. Diagn. Res., 8(7):ZD10-1, 2014.

Shapira, Y.; Mischler, W. A. \& Kuftinec, M. M. The displaced mandibular canine. A. S. D. C. J. Dent. Child., 49(5):362-4, 1982

Taguchi, Y.; Kurol, J.; Kobayashi, H. \& Noda, T. Eruption disturbances of mandibular permanent canines in Japanese children. Int. J. Paediatr. Dent., 11(2):98-102, 2001.

Thoma, K. H. Oral Surgery. $2^{\text {nd }}$ ed. St. Louis, Mosby, 1952.

Tyagi, P. \& Singla, S. Complex composite odontoma. Int. J. Clin. Pediatr. Dent., 3(2):117-20, 2010

Vaid, S.; Ram, R.; Bhardwaj, V. K.; Chandel, M.; Jhingta, P.; Negi, N. \& Sharma, D. Multiple compound odontomas in mandible: A rarity. Contemp. Clin. Dent., 3(3):341-3, 2012.

\author{
Correspondig author: \\ Dr. Ramon Fuentes \\ Facultad de Odontología \\ Universidad de La Frontera \\ Manuel Montt 112 \\ Casilla 54-D \\ Temuco \\ CHILE
}

E-Mail: ramon.fuentes@ufrontera.cl

Received: 03-01-2017

Accepted: 21-03-2017 